\title{
Establishment of the optimum two-dimensional electrophoresis system of ovine ovarian tissue
}

\author{
J.L. Jia, L.P. Zhang, J.P. Wu, J. Wang and Q. Ding \\ The Key Laboratory of Animal Genetic Breeding and Reproduction, \\ College of Animal Science and Technology, Gansu Agricultural University, \\ Lanzhou, China \\ Corresponding author: L.P. Zhang \\ E-mail: zhangliping@gsau.edu.cn
}

Genet. Mol. Res. 13 (3): 6528-6538 (2014)

Received January 10, 2014

Accepted March 18, 2014

Published August 26, 2014

DOI http://dx.doi.org/10.4238/2014.August.26.3

\begin{abstract}
Lambing performance of sheep is the most important economic trait and is regarded as a critic factoring affecting the productivity in sheep industry. Ovary plays the most roles in lambing trait. To establish the optimum two-dimensional electrophoresis system (2-DE) of ovine ovarian tissue, the common protein extraction methods of animal tissue (trichloroacetic acid/acetone precipitation and direct schizolysis methods) were used to extract ovine ovarian protein, and 17-cm nonlinear immobilized PH 3-10 gradient strips were used for 2-DE. The sample handling, loading quantity of the protein sample, and isoelectric focusing (IEF) steps were manipulated and optimized in this study. The results indicate that the direct schizolysis III method, a 200$\mu \mathrm{g}$ loading quantity of the protein sample, and IEF steps II $\left(20^{\circ} \mathrm{C}\right.$ active hydration, $14 \mathrm{~h} \rightarrow 500 \mathrm{~V}, 1 \mathrm{~h} \rightarrow 1000 \mathrm{~V} 1 \mathrm{~h} \rightarrow 1000-9000 \mathrm{~V}, 6 \mathrm{~h} \rightarrow 80,000$ $\mathrm{VH} \rightarrow 500 \mathrm{~V} 24 \mathrm{~h}$ ) are optimal for 2-DE analysis of ovine ovarian tissue. Therefore, ovine ovarian tissue proteomics 2-DE was preliminarily established by the optimized conditions in this study; meanwhile, the conditions identified herein could provide a reference for ovarian
\end{abstract}


sample preparation and 2-DE using tissues from other animals.

Key words: Ovine; Ovarian; Protein extraction; Bradford method; Two-dimensional electrophoresis system; PDQuest

\section{INTRODUCTION}

The lambing performance of sheep is an important economic trait and regarded as a critical factor affecting productivity in the sheep industry; moreover, the twinning trait is regarded as ideal with regard to lambing performance and is favored in the sheep industry (Fogarty and Mulholland, 2012). There are many multi-breed sheep in China and abroad, and the primary gene of multi-breed sheep lambs (i.e., $\mathrm{Fec}$ ), which improves the fecundity of sheep, has been described (Davis et al., 1982). However, the lambs of multiple sheep are generally weaker, have smaller birth weights, and higher mortality rates, which can affect sheep management and increase feed costs ( $\mathrm{Li}$ and Xue, 2004). Therefore, multi-breed sheep are not suitable for intensive production or the standardized management of sheep farming.

Long-term studies and observations of twin animals indicate that the twinning trait is mainly controlled by genetic factors. Thus, identifying the major genes of the sheep twinning trait and molecular markers for breeding programs are key to improving the economic benefits of sheep farming. At present, there are almost no reports investigating the mechanisms underlying the molecular genetics and regulation of the sheep twinning trait in China and abroad (Yang et al., 2010; He and Liu, 2010), particularly with regard to proteomics.

The first step in proteomic research is the two-dimensional electrophoresis system (2DE), which is regarded as key for the success of a study (Görg, 2009). Currently, only 10003000 protein spots (spot) can be distinguished by 2-DE, but there are many known proteins that can be obtained from samples. Therefore, sample separation is necessary.

There are differences in the protein compositions among different species and tissues. Therefore, different sample handling methods are required for different tissues from the same species or the same tissues from different species. The 2-DE of human ovarian tissues has been previously published. However, there are no reports detailing the extraction method for ovine ovaries. The structure of ovine ovarian tissue is complex; it is comprised of lipids and other interfering substances. In this study, the different sample handling methods, loading quantities of protein samples, and isoelectric focusing (IEF) steps were selected and optimized, and the purpose was to preliminarily establish the optimum 2-DE settings for analyzing ovine ovarian tissues.

\section{MATERIAL AND METHODS}

\section{Samples and data collection}

Animal care and use in this study were consistent with the animal care and use requirements of Gansu Agricultural University. Ovarian tissue samples were obtained from healthy and multiparous ewes (2-3 years old) of Mongolian Sheep $(\mathrm{N}=4)$, Poll Dorset sheep 
$(\mathrm{N}=4)$, and Small Tail Han sheep $(\mathrm{N}=4)$; they were procured from live animals and from bloodletting of the jugular vein after slaughter from the Huajia Sheep Breeding Farm (Dingxi, Gansu, China). After washing with ultrapure water, all ovarian tissue samples were placed in $5.0 \mathrm{~mL}$ cryogenic vials (Shanghai Zurui Biological Technology Co., Ltd.) and stored in liquid nitrogen.

\section{Chemicals and reagents}

All chemicals were purchased from Sigma, unless otherwise stated.

\section{Protein extraction}

\section{Trichloroacetic acid (TCA)/acetone precipitation}

Ovarian tissue was placed in the mortar and ground in liquid nitrogen into a powder. Then, $0.1 \mathrm{~g}$ ovarian tissue sample was added to $1.5 \mathrm{~mL} 10 \%$ TCA/acetone $(0.07 \%$ $\beta$-mercaptoethanol) and homogenized with an amplitude of $22 \%$ via ultrasonic amplitude in ice (pulsed ultrasound was programmed to turn on for $0.1 \mathrm{~s}$ and then off for $1 \mathrm{~s}$, for $60 \mathrm{~s}$ ). After storing overnight at $4^{\circ} \mathrm{C}$, samples were centrifuged at $4{ }^{\circ} \mathrm{C}$ and $35,000 \mathrm{rpm}$ for $30 \mathrm{~min}$, and the supernatant was removed. Sediment was added to $1.5 \mathrm{~mL}$ acetone $(0.07 \% \beta$-mercaptoethanol $)$ and repetitively scrubbed using a pipette. Samples were placed in $4^{\circ} \mathrm{C}$ for $20 \mathrm{~min}$; centrifuged at $4^{\circ} \mathrm{C}$ and 35,000 rpm for $20 \mathrm{~min}$; and the supernatant was removed; this step was repeated twice. Sediment was added to $1.5 \mathrm{~mL} 90 \%$ acetone $(0.07 \% \beta$-mercaptoethanol) and repetitively scrubbed using a pipette. Samples were placed in $4^{\circ} \mathrm{C}$ for $20 \mathrm{~min}$; centrifuged at $4^{\circ} \mathrm{C}$ and $35,000 \mathrm{rpm}$ for $20 \mathrm{~min}$; and the supernatant was removed; this step was repeated twice. Sediment was added to a lysis buffer (i.e., $0.1 \mathrm{~g}$ ovarian tissue samples were added to $1 \mathrm{~mL}$ lysis buffer) and then dried via protein frozen drier. The lysis buffer was comprised of $7 \mathrm{M}$ urea, $2 \mathrm{M}$ thiourea, 4\% CHAPS, 0.5\% Bio-Lyte $\mathrm{pH} 3-10$ (Bio-Rad), and $1 \mathrm{mM}$ protease inhibitor cocktail. After vibrated at room temperature for $2 \mathrm{~h}$, the sample was centrifuged at $4{ }^{\circ} \mathrm{C}, 35,000$ rpm for $30 \mathrm{~min}$. The total protein content was measured using the Bradford method (IMPLEN, NanoPhotometer ${ }^{\mathrm{TM}}$, Germany), and the lysates were stored at $-80^{\circ} \mathrm{C}$ for future use.

\section{Direct schizolysis I, II, and III}

The ovarian tissue was placed in a mortar and ground in liquid nitrogen into a powder. Then, $0.1 \mathrm{~g}$ ovarian tissue sample was added to $1 \mathrm{~mL}$ lysis buffer. Samples were lysed at room temperature for $30 \mathrm{~min}$ followed by homogenization with $22 \%$ via ultrasonic amplitude in ice water (pulsed ultrasound was programmed to turn on for $0.1 \mathrm{~s}$ and then off for $1 \mathrm{~s}$, for a total of $60 \mathrm{~s}$ ). Samples were placed in $4^{\circ} \mathrm{C}$ for $4 \mathrm{~h}$ and then centrifuged at $35,000 \mathrm{rpm}$ at $4^{\circ} \mathrm{C}$ for $1 \mathrm{~h}$; the supernatant was retained. The protein solution was exchanged into $50 \mathrm{mM}$ triethylammonium bicarbonate, $\mathrm{pH}$ 9, using a PD10 column according to manufacturer instructions (GE Healthcare). Total protein content was measured using the Bradford method (IMPLEN, NanoPhotometer ${ }^{\mathrm{TM}}$ ), and the lysates were stored at $-80^{\circ} \mathrm{C}$ for future use. The direct schizolysis I lysis buffer formula was: $7 \mathrm{M}$ urea, $2 \mathrm{M}$ thiourea, 4\% CHAPS, 0.5\% Bio-Lyte $\mathrm{pH}$ 3-10 (Bio$\mathrm{Rad}), 40 \mathrm{mM}$ DTT, and $1 \mathrm{mM}$ protease inhibitor cocktail. The direct schizolysis II lysis buffer 
formula was: $7 \mathrm{M}$ urea, $2 \mathrm{M}$ thiourea, 2\% CHAPS, 0.5\% Bio-Lyte $\mathrm{pH}$ 3-10 (Bio-Rad), 2\% Triton X-100, $40 \mathrm{mM}$ DTT, and $1 \mathrm{mM}$ protease inhibitor cocktail. The direct schizolysis III lysis buffer formula was as follows: $7 \mathrm{M}$ urea, $2 \mathrm{M}$ thiourea, $4 \%$ CHAPS, 0.5\% Bio-Lyte $\mathrm{pH}$ 3-10 (Bio-Rad), $80 \mathrm{mM}$ DTT, $1 \mathrm{mM}$ protease inhibitor cocktail, and $40 \mathrm{mM}$ Tris.

\section{Protein quantification}

The Bradford Protein Assay Kit (Shanghai Zurui Biological Technology Co., Ltd.) was used to detect protein quantification. A total of $5 \mathrm{mg} / \mathrm{mL}$ bovine serum albumin (BSA) was completely dissolved into ultrapure water $(0.5 \mathrm{mg} / \mathrm{mL}$ final BSA concentration). BSA standard liquid was added to $1.5 \mathrm{~mL}$ Eppendorf tubes (i.e., $0,1,2,4,8$, and $10 \mu \mathrm{L}$ ); ultrapure water was then added to each tube to a final volume of $20 \mu \mathrm{L}$. Then, $10 \mu \mathrm{L}$ samples were added into additional Eppendorf tubes and ultrapure water was added to a volume of $20 \mu \mathrm{L}$. A total of $200 \mu \mathrm{L}$ G-250 staining solution was added into each Eppendorf tube. Samples were placed at room temperature for 3-5 min. A $595 \mathrm{~nm}$ OD value was determined by ultramicro spectrophotometer (IMPLEN) and a standard curve was visualized. Protein contents of the samples were calculated by using the standard curve.

\section{2-DE}

PROTEAN ${ }^{\circledR}$ IEF Cell PROTEAN (Bio-Rad) was selected for 2-DE. We utilized 17$\mathrm{cm}$ nonlinear immobilized $\mathrm{pH}$ 3-10 gradient strips for IEF. The samples and loading buffer (7 M urea, $2 \mathrm{M}$ thiourea, 4\% CHAPS, 0.5\% Bio-Lyte pH 3-10, $40 \mathrm{mM}$ DTT, and $0.002 \%$ bromophenol blue) are total $450 \mu \mathrm{L}$. In this study, 3 loading quantities (i.e., 150, 200, and 250 $\mu \mathrm{g}$ ) of the protein sample were compared and IEF steps were IEF II of Table 1. Three kinds of IEF steps were compared, and the loading quantity of the protein sample was $200 \mu \mathrm{g}$ (Table 1). A $12 \%$ SDS-PAGE was used for secondary separation. The SDS-PAGE steps were as follows: $50 \mathrm{~V}$ for $1 \mathrm{~h}$ and $150 \mathrm{~V}$ for $9 \mathrm{~h}$. Then, gels were dyed by Coomassie brilliant blue G-250, and ultrapure water was used for discoloration. Finally, the gels were imaged by the UMAX scanner (scanning parameters: 256 gray and 600 dpi resolution) and analyzed by PDQuest 8.0 (detection parameters: smooth 3, min area 10, and saliency 250).

\begin{tabular}{|c|c|c|c|c|c|c|}
\hline \multirow[t]{2}{*}{ Steps } & \multicolumn{2}{|c|}{ IEF I } & \multicolumn{2}{|c|}{ IEF II } & \multicolumn{2}{|c|}{ IEF III } \\
\hline & Voltage $(\mathrm{V})$ & Time & Voltage (V) & Time & Voltage (V) & Time \\
\hline Hydration & 50 & $14 \mathrm{~h}$ & 50 & $14 \mathrm{~h}$ & 50 & $14 \mathrm{~h}$ \\
\hline Si & 500 & $1 \mathrm{~h}$ & 500 & $1 \mathrm{~h}$ & 500 & $1 \mathrm{~h}$ \\
\hline S2 & 1000 & $1 \mathrm{~h}$ & 1000 & $1 \mathrm{~h}$ & 1000 & $1 \mathrm{~h}$ \\
\hline S3 & 9000 & $6 \mathrm{~h}$ & 9000 & $6 \mathrm{~h}$ & 9000 & $6 \mathrm{~h}$ \\
\hline S4 & 9000 & $60,000 \mathrm{VH}$ & 9000 & $80,000 \mathrm{VH}$ & 9000 & $100,000 \mathrm{VH}$ \\
\hline S5 & 500 & $24 \mathrm{~h}$ & 500 & $24 \mathrm{~h}$ & 500 & $24 \mathrm{~h}$ \\
\hline
\end{tabular}

\section{Statistical analysis}

For the purpose of this analysis, we were interested in comparing protein extraction 
contents and extraction effects between the different conditions. Protein extraction contents and the number of total protein spots were analyzed by the SAS 9.0 software according to ANOVA; the extraction effects were analyzed via PDQuest 8.0 software.

\section{RESULTS}

\section{Protein quantification of different sample handling methods}

Bradford Protein Assay Kit (MBCHEMTM) was used to detect protein quantification. The standard curve is shown in Figure $1[y=0.3545 x-0.0201 ; R 2=0.9886$; RSD was $1.28 \%$ $(\mathrm{N}=5)]$. The sample protein contents are shown in Table 2. These results show that the protein contents of the different sample handling methods significantly differed. The protein contents of the direct schizolysis I, II, and III methods were significantly greater than those of the TCA/ acetone precipitation method $(\mathrm{P}<0.01)$; however, there were no significant differences among the direct schizolysis I, II, and III methods $(\mathrm{P}>0.01)$.

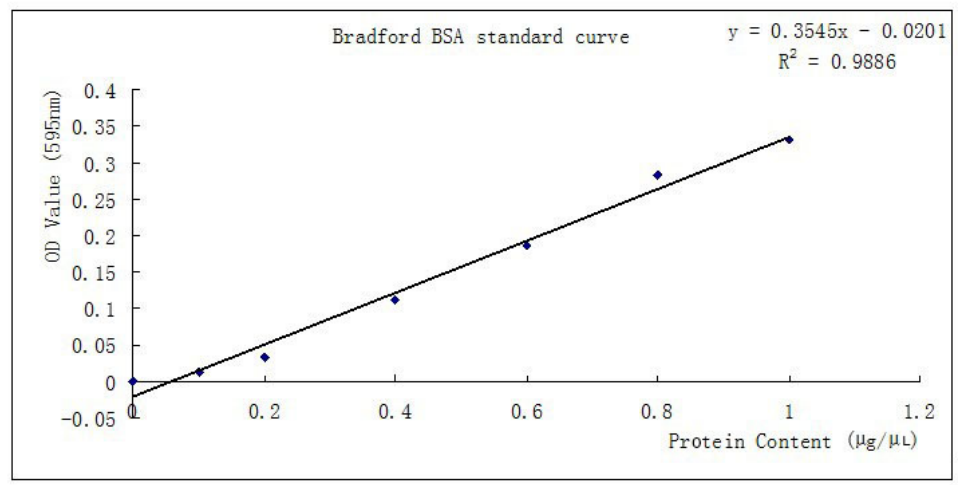

Figure 1. Standard curve of bradford method.

\begin{tabular}{|c|c|}
\hline Methods & Protein content $(\mu \mathrm{g} / \mu \mathrm{L})$ \\
\hline TCA/acetone precipitation & $3.7978 \pm 1.2056^{\mathrm{B}}$ \\
\hline Direct schizolysis I & $5.8436 \pm 1.0941^{\mathrm{A}}$ \\
\hline Direct schizolysis II & $5.7683 \pm 0.6547^{\mathrm{A}}$ \\
\hline Direct schizolysis III & $5.9914 \pm 1.2946^{\mathrm{A}}$ \\
\hline
\end{tabular}

Capital letters indicate the level of 0.01 ; the different superscript capital letters within the same column differ highly significantly.

\section{2-DE of the different sample handling methods}

We utilized $17 \mathrm{~cm}$ nonlinear immobilized $\mathrm{pH}$ 3-10 gradient strips for IEF; the loading quantity of the protein sample was $200 \mu \mathrm{g}$. The IEF steps were: $20^{\circ} \mathrm{C}$ active hydration, 14 $\mathrm{h} \rightarrow 500 \mathrm{~V}, 1 \mathrm{~h} \rightarrow 1000 \mathrm{~V}, 1 \mathrm{~h} \rightarrow 1000-9000 \mathrm{~V}, 6 \mathrm{~h} \rightarrow 80,000 \mathrm{VH}, 500 \mathrm{~V}, 24 \mathrm{~h}$; the SDS-PAGE concentration was $12 \%$ and the SDS-PAGE step was $1 \mathrm{~h}$ at $50 \mathrm{~V}$ and $9 \mathrm{~h}$ at $150 \mathrm{~V}$.

The extraction effects are shown in Figure 2 . The protein spots were mainly concen- 
trated within the molecular mass range of $15-90 \mathrm{kDa}$, with an isoelectric point of 4-9. In the oval area, the protein spots and 2-DE resolution of the direct schizolysis III method were better than those of the direct schizolysis I and II, and TCA/acetone precipitation methods, and there were almost no spots observed via TCA/acetone precipitation. The high amount of proteins via TCA/acetone precipitation and direct schizolysis I and II were greater than those of direct schizolysis III, and the smearing phenomena were notable for TCA/acetone precipitation. The characteristics for 2-DE of direct schizolysis III included high resolution and an absence of the smearing phenomena in the rectangular area.
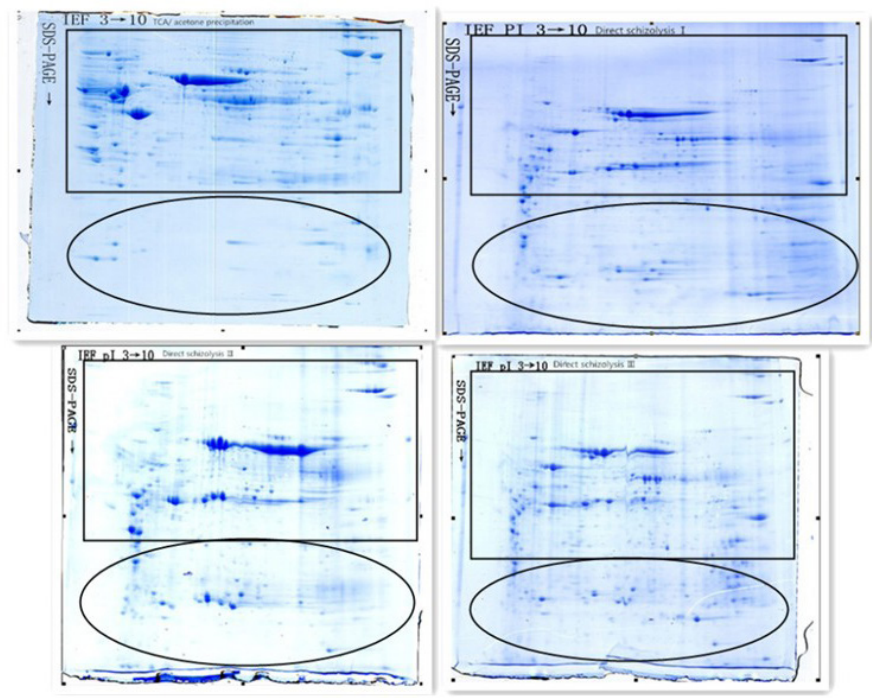

Figure 2. Two-dimensional electrophoresis system of different sample handling methods.

The total protein spots of the different sample handling methods were analyzed by SAS 9.0 (Table 3; $\mathrm{F}=6.58, \mathrm{P}<0.0001, \mathrm{~N}=12$ ). The number of protein spots obtained using the different sample handling methods exhibited significant differences; that of the TCA/acetone precipitation method was significantly lower than that of the direct schizolysis I, II, and III methods; that of the direct schizolysis II method was significantly lower than that of the direct schizolysis I and III methods. Moreover, there were no significant differences between the direct schizolysis I and III methods, but the total number of protein spots via direct schizolysis I was greater than that via direct schizolysis III.

Table 3. Total protein spots of the different methods.

\begin{tabular}{lr}
\hline Methods & Total protein spots \\
\hline TCA/acetone precipitation & $980 \pm 84^{\mathrm{C}}$ \\
Direct schizolysis I & $1203 \pm 108^{\mathrm{A}}$ \\
Direct schizolysis II & $1074 \pm 141^{\mathrm{B}}$ \\
Direct schizolysis III & $1198 \pm 96^{\mathrm{A}}$ \\
\hline
\end{tabular}

Capital letters show the level of 0.01 ; the different superscript capital letters within the same column differ highly significantly. 


\section{2-DE of the different loading quantities of the protein sample}

In this study, 3 different loading quantities of the protein sample (i.e., 150, 200, and $250 \mu \mathrm{g}$ ) were used for 2-DE; the sample volume was $450 \mu \mathrm{L}$. When the loading quantity of the protein sample was $150 \mu \mathrm{g}$, the number of protein spots was minimal, the colors were very light, and many low-abundance proteins could not be detected via PDQuest 8.0. When the loading quantity of the protein sample was $250 \mu \mathrm{g}$, the color of the protein spots was very deep, the samples could not be separated by $2-\mathrm{DE}$, and the high-abundance proteins disguised the low-abundance proteins. The resolution of the $200-\mu \mathrm{g}$ loading quantity of the protein sample was better than that of the other loading quantities (Figure 3).

\section{2-DE of the different IEF steps}

In this study, 3 kinds of IEF steps were used for 2-DE. When the focus was $60,000 \mathrm{VH}$, the number of protein spots was minimal, the colors were very light, and many low-abundance proteins could not be detected via PDQuest 8.0. When the focus was $100,000 \mathrm{VH}$, the color of the protein spots was very deep and smearing phenomena were notable. At a focus of 80,000 $\mathrm{VH}$, high resolution and the absence of smearing phenomena were observed (Figure 4).

\section{2-DE of ovine ovarian}

Different optimization conditions were used to establish the 2-DE of ovine ovarian tissue, and the result was repeated in triplicate (Figure 5). The optimal conditions were as follows: the direct schizolysis III protein sample handling method; a loading quantity for the protein sample of $200 \mu \mathrm{g}$; a sample volume of $450 \mu \mathrm{L}$; the IEF steps of $20^{\circ} \mathrm{C}$ active hydration, $14 \mathrm{~h} \rightarrow 500 \mathrm{~V}, 1 \mathrm{~h} \rightarrow 1000 \mathrm{~V}, 1 \mathrm{~h} \rightarrow 1000-9000 \mathrm{~V}, 6 \mathrm{~h} \rightarrow 80,000 \mathrm{VH} \rightarrow 500 \mathrm{~V} 24 \mathrm{~h}$; an SDS-PAGE concentration of $12 \%$ and condition of $1 \mathrm{~h}$ at $50 \mathrm{~V}$ and $9 \mathrm{~h}$ at $150 \mathrm{~V}$.

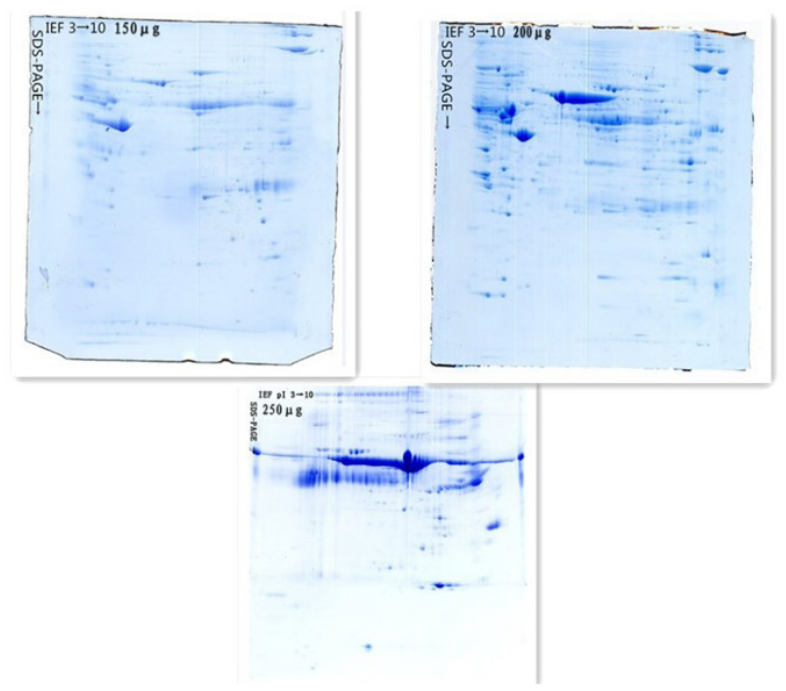

Figure 3. Two-dimensional electrophoresis system of the different loading quantity of protein sample. 

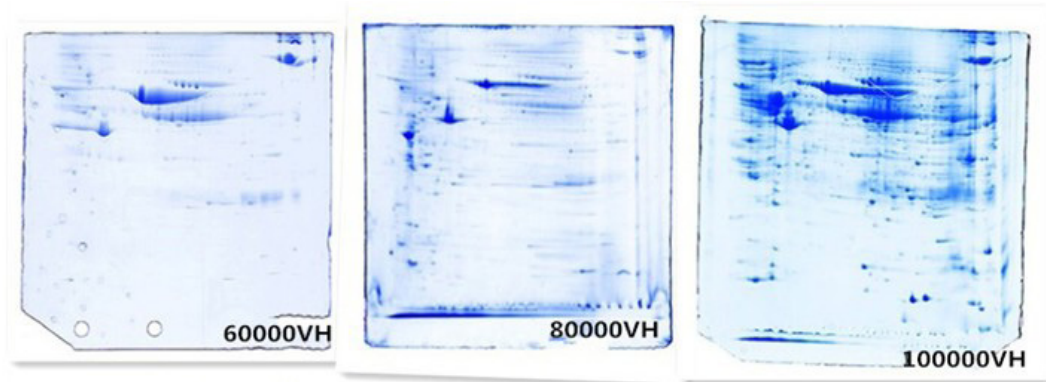

Figure 4. Two-dimensional electrophoresis system of the different isoelectric focusing steps.

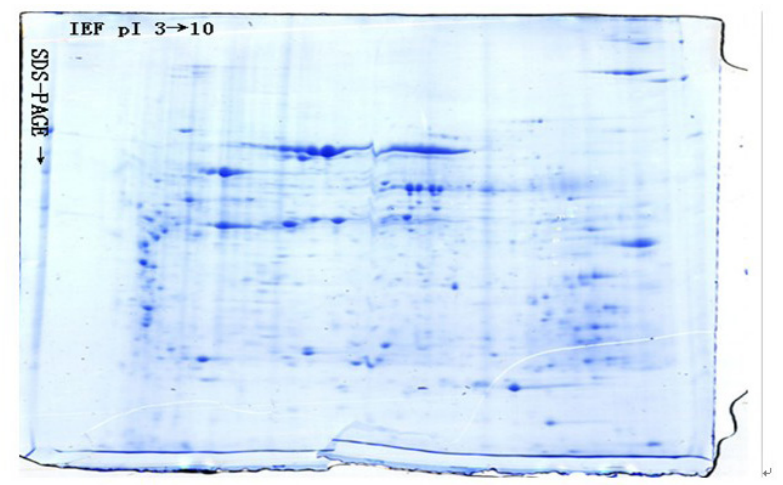

Figure 5. Two-dimensional electrophoresis system of ovine ovarian.

\section{DISCUSSION}

\section{Protein extraction}

\section{TCA/acetone precipitation}

The TCA/acetone precipitation method is often used to extract proteins from plants and animal liver tissues (Yang and Zhao, 2007). The extracts have almost no salt or interference (e.g., pigment, lipid, and secondary metabolites), and it can reduce protein degradation (Tsugita and Kamo, 1999). Urea cooperates with thiourea as a denaturant that can enhance the solubility of hydrophobic proteins. CHAPS can slow protein precipitation polymerization by hydrophobic bonds and improve the solubility of proteins. Bio-Lyte $\mathrm{pH}$ 3-10 can dissolve the ionic strength of a protein. The protease inhibitor cocktail can prevent protein degradation. This is the first study to use the TCA/acetone precipitation method to extract ovine ovarian proteins. However, the protein extraction effect is not ideal and protein content can be significantly lower than that of the other 3 methods; in addition, the proteins of the alkaline side experience great losses. The main reason is the repetitive scrubbing that could lead to protein losses, especially with regard to basic proteins. This result is similar to that obtained by Wang et al. (2011) and Lai and $\mathrm{Xu}$ (2010). Therefore, this method is not the optimum extraction method for ovine ovarian proteins. 


\section{Direct schizolysis I}

The direct schizolysis I method is commonly used in the protein extraction of animal tissues (Saravanan and Rose, 2004). Direct schizolysis I increases the level of DTT by $40 \mathrm{mM}$ from that of the basic TCA/acetone precipitation method. DTT is an unusually strong reducing agent, owing to its high conformational propensity to form a 6-membered ring with an internal disulfide bond. DTT can deoxygenize the disulfide bond of polypeptide chains and prevent deactivation via protein sulfhydryl group oxidation. 2-DE showed that the total number of protein spots were significantly greater than that via the TCA/acetone precipitation method but the resolution was low; the smearing phenomena were notable in polymer proteins and the basic proteins had horizontal stripes. Therefore, future optimization is necessary.

\section{Direct schizolysis II}

The direct schizolysis II method was similar to that of the direct schizolysis I, except that the $2 \%$ CHAPS was replaced by Triton X-100. Triton X-100 is a kind of surfactant that has both hydrophobic and hydrophilic sides. It can dissociate membrane proteins from the membrane. However, Triton X-100 cannot maintain enzymatic activity. Excessive Triton X-100 can destroy the protein structure by destroying the hydrophilic layer of the protein surface and reducing enzymatic activity (Luche et al., 2003). Thus, only 2\% CHAPS was replaced by Triton X-100 in this study. The results show that the vertical smearing and horizontal striations significantly improved. However, protein contents and total protein spots were less than those obtained via direct schizolysis I, especially with regard to alkaline side proteins. The spot resolution of 2-DE was greater than that of the direct schizolysis I method; the reason for this difference may be that Triton X-100 preferentially dissolves insoluble membrane proteins, but the dissolving capacity for most of the other proteins is poorer than that of CHAPS, especially with regard to basic proteins. Therefore, this method also needs to be optimized in the future.

\section{Direct schizolysis III}

In comparison to the direct schizolysis I method, the concentration of DTT in the direct schizolysis III method increased from 40 to $80 \mathrm{mM}$; there was also an additional 40 $\mathrm{mM}$ Tris. The increased amount of DTT can compensate for the loss in the alkaline region for IEF and improve the dissolution of the basic protein (Herbert, 1999). Tris has a high buffering capacity; the addition of $40 \mathrm{mM}$ Tris can provide a suitable environment for a reduction in disulfide bonds, inhibit some protease activity, and increase the solubility of a protein. The number of protein spots obtained using this method was less than that of the direct schizolysis I method; however, it could completely satisfy the requirements of successive tests and obtain a high-resolution 2-DE profile. Thus, the direct schizolysis III method is conformable for ovine ovarian sample preparation.

\section{2-DE of the different loading quantities of the protein sample and the different IEF steps}

The loading quantity of the protein sample can greatly influence 2-DE; high or low 
loading quantities of a protein sample cannot satisfy the needs of the 2-DE analysis (Zhou and Wang, 2013). The high loading quantity of a protein sample could influence the high-abundance proteins and disguise low-abundance proteins; thus, further analysis would be difficult. Meanwhile, the excess in proteins could subside in the focal slot and block focal aperture. The low loading quantity of a protein sample did not meet the study requirements. In this study, the results were in accordance with Huang and Zhu (2013); when the loading quantity of a protein sample was $200 \mu \mathrm{g}$, the 2-DE did not exhibit smearing phenomena, and the resolution was better when compared to that of the other quantities.

IEF parameters were directly related to protein separation (Nagalla et al., 2007). Long time focus and short time focus would cause smearing phenomena of the protein spots and would not yield improvements in 2-DE. In this study, the results were similar to those of Li and Jiang (2012); a focus of $80,000 \mathrm{VH}$ yielded high resolution and the absence of smearing phenomena.

\section{CONCLUSION}

This study combined the Bradford method, 2-DE, and PDquest 8.0 to analyze the results of the different extraction methods of ovine ovarian proteins. The optimal conditions were as follows: the protein extraction method of direct schizolysis III; a protein sample loading quantity of $200 \mu \mathrm{g}$; a sample volume of $450 \mu \mathrm{L}$; IEF steps of $20^{\circ} \mathrm{C}$ active hydration, 14 $\mathrm{h} \rightarrow 500 \mathrm{~V}, 1 \mathrm{~h} \rightarrow 1000 \mathrm{~V}, 1 \mathrm{~h} \rightarrow 1000-9000 \mathrm{~V}, 6 \mathrm{~h} \rightarrow 80000 \mathrm{VH} \rightarrow 500 \mathrm{~V}, 24 \mathrm{~h}$; and an SDS-PAGE concentration of $12 \%$ and condition of $1 \mathrm{~h}$ at $50 \mathrm{~V}$ and $9 \mathrm{~h}$ at $150 \mathrm{~V}$.

\section{ACKNOWLEDGMENTS}

Research supported by National Natural Science Foundation of China, Study of the Regulation Mechanism and Signaling Molecules of Sheep Twinning Traits though Protein Different Expression and its Dynamic Composition (\#31260547), and the Animal Husbandry Department of Gansu Province, Study of the Regulation Mechanism of Sheep Twinning Traits (\#GNSW-2012-24).

\section{REFERENCES}

Davis GH, Montgomery GW, Allison AJ, Kelly RW, et al. (1982). Segregation of a major gene influencing fecundity in progeny of Booroola sheep. New Zealand J. Agr. Res. 25: 525-529.

Fogarty NM and Mulholland JG (2012). Annual lambing performance of crossbred ewes in out-of-season and accelerated lamb production systems. Anim. Prod. Sci. 53: 1093-1100.

Görg A, Drews O, Lück C, Weiland F, et al. (2009). 2-DE with IPGs. Electrophoresis 30 Suppl. 1: S122-S132.

He X and Liu Y (2010). Mongolian sheep FSHB gene cDNA cloning and sequence analysis. Heilongjiang Anim. Sci. Vet. Med. 2: 39-41.

Herbert B (1999). Advances in protein solubilisation for two-dimensional electrophoresis. Electrophoresis 20: 660-663.

Huang M and Zhu G (2013). Establishment of two-dimensional electrophoresis for proteme of liver from muscovy duck experimentally infected with norvel duck reovirus. Chin. Agr. Sci. Bull. 29: 19-24.

Lai D and Xu H (2010). Establishment of protein extraction methods for two-dimensional electrophoresis in Tephrosia vogelii hook f. leaf. Biotechn. Bull. 4: 103-107.

Li Y and Xue H (2004). Booroola Merino sheep FecB genetic research and application in sheep breeding. China Herbivores 24: 44-46. 
Li C and Jiang Y (2012). Establishment of 2-D PAGE system for leaf protein of Hibiscus hamabo. J. SW. Forest. Univ. 32: 30-35.

Luche S, Santoni V and Rabilloud T (2003). Evaluation of nonionic and zwitterionic detergents as membrane protein solubilizers in two-dimensional electrophoresis. Proteomics 3: 249-253.

Nagalla SR, Canick JA, Jacob T, Schneider KA, et al. (2007). Proteomic analysis of maternal serum in down syndrome: identification of novel protein biomarkers. J. Proteome Res. 6: 1245-1257.

Saravanan RS and Rose JK (2004). A critical evaluation of sample extraction techniques for enhanced proteomic analysis of recalcitrant plant tissues. Proteomics 4: 2522-2532.

Tsugita A and Kamo M (1999). 2-D electrophoresis of plant proteins. Meth. Mol. Biol. 112: 95-97.

Wang WG, Wang YL, Zhang ZP, Feng JJ, et al. (2011). Preparation methods of ovary protein samples in green mud crab Scylla paramamosain for two-dimensional electrophoresis. Fish. Sci. 6: 252-255.

Yang Y and Zhao X (2007). Preparation of protein samples from mammary tissues and its 2-DE analysis in dairy cow. Acta Vet. Zootech. Sin. 38: 846-850.

Yang Y, Shao K and Da L (2010). Study on theBMP15 gene as candidate genes for fecundity in mongolian sheep doublelambs group. Agr. Boreall-Sin. 25: 44-49.

Zhou X, Yaun K, Yang L and Wang Z (2013). Influence of protein purification and loading quantity on the 2-DE protein patterns of maize leaf. Chin. J. Trop. Agr. 33: 36-45. 